\title{
Matching national forest policies and management practices for climate change adaptation in Burkina Faso and Ghana
}

\author{
Fobissie B. Kalame • Johnson Nkem • Monica Idinoba • \\ Markku Kanninen
}

Received: 24 April 2008 / Accepted: 4 September 2008 /

Published online: 10 October 2008

C The Author(s) 2008. This article is published with open access at Springerlink.com

\begin{abstract}
Many studies have suggested various kinds of forest policies, management planning and practices to help forests adapt to climate change. These recommendations are often generic, based mostly on case studies from temperate countries and rarely from Africa. We argue that policy and management recommendations aimed at integrating adaptation into national forest policies and practices in Africa should start with an inventory and careful examination of existing policies and practices in order to understand the nature and extent of intervention required to influence the adaptation of forest ecosystems to climate change. This paper aims to contribute to closing this gap in knowledge detrimental to decision making through the review and analysis of current forest policies and practices in Burkina Faso and Ghana and highlighting elements that have the potential to influence the adaptation of forest ecosystems to climate change. The analysis revealed that adaptation (and mitigation) are not part of current forest policies in Burkina Faso and Ghana, but instead policies contain elements of risk management practices which are also relevant to the adaptation of forest ecosystems. Some of these elements are found in policies on the management of forest fires, forest genetic resources, non-timber resources, tree regeneration and silvicultural practices. To facilitate and enhance the management of these elements, a number of recommendations are suggested. Their implementation will require experienced and well-trained forestry personnel, financial resources, socio-cultural and political dimensions, and the political will of decision makers to act appropriately by formulating necessary policies and mainstreaming adaptation into forest policy and management planning.
\end{abstract}

\footnotetext{
F. B. Kalame $(\bowtie) \cdot$ M. Idinoba

Centre for International Forestry Research, P.B. 9478 Ouagadougou 06, Burkina Faso e-mail: f.kalame@cgiar.org
}

F. B. Kalame

Viikki Tropical Resources Institute, University of Helsinki, P.O. Box 27, Latokartanonkaari 9, FIN-00014, Finland 
Keywords Adaptation - Burkina Faso - Climate change - Forest ecosystems ·

Forest management practices $\cdot$ Forest policies $\cdot$ Ghana

\section{Introduction}

Climate change and climate variability are already significantly affecting forest ecosystems in West Africa (Gonzalez 2001; Nicholson 2001; IPCC 2007), with cases of increased tree mortality and declines in forest species richness and densities of trees. There is report of a southward shift of Sudanian and Guinean tree species and a southward expansion of Sahelian tree species (Gonzalez 2001). According to the first national communication of Burkina Faso submitted to the United Nation Framework Convention on Climate Change, forest is among the most vulnerable sectors to climate change impacts in Burkina Faso (SP/ CONAGESE 2001; SP/CONEDD 2007). In Ghana on other hand, forest is considered vulnerable, though not amongst the most vulnerable sectors, but rather recognised as a carbon sink and provider of other services to other sectors considered most vulnerable, such as water, agriculture and coastal areas, through forest protection and management (EPA 2000).

Forest ecosystems in Burkina Faso and Ghana are vulnerable to both climatic and nonclimatic factors. Climate change manifests in these countries mainly through intense and frequent extreme climate events of (a) high rainfall variability, leading to droughts or floods with consequences of soil erosion, difficult tree regeneration and growth, migration and extinction of forest flora and fauna in specific locations, (b) high temperatures, (c) windstorms, and (d) forest fires (EPA 2000; SP/CONEDD 2007). Forests are also severely exposed and sensitive to human pressure (non-climatic factor) including rapid population growth, deforestation, poverty and government policies (FAO 2000; Gray and Kevane 2001; Blay et al. 2004; Kalame et al. 2008). Projections from general circulation and other models in Burkina Faso indicate that by 2025 and 2050, temperature will rise by an average of $0.8^{\circ} \mathrm{C}$ and $1.7^{\circ} \mathrm{C}$, respectively, while overall rainfall will decrease by $3.4 \%$ and $7.3 \%$ for the respective years (SP/CONEDD 2007). For Ghana, these models indicate that by 2100 , temperature is expected to rise by an average of $2-3^{\circ} \mathrm{C}$, while by 2030 and 2050 there will be a general decrease in rainfall (EPA 2000). The projected high temperatures in combination with decreasing rainfall and periodic droughts coupled with anthropogenic forces pose a great risk for forest ecosystem productivity.

Forest ecosystems provide many goods and services valuable to society, ranging from wood-based (e.g. industrial wood, fuelwood) to non-wood forest goods (e.g. plant and animal products) and to forest services such as niche habitats for other organisms as well as regulatory, recreational and cultural services (FAO 2006). Forest-dependent communities in Burkina Faso and Ghana rely on these goods and services for their livelihoods especially for adaptation during events like droughts, floods and crop failures. These goods and services are also beneficial to forest and other forest- or tree-dependent sectors such as livestock, water, energy and agriculture, which contribute to the overall national economic development. For example, the forest sector contributes $3 \%$ and $6 \%$, respectively, to the gross domestic products of Burkina Faso and Ghana (CARE International 2004; MECV 2004). Appropriate adaptation strategies, which include good policies and management strategies, are required to reduce the impacts of climate change in these countries. This is crucial, because otherwise the benefits these communities, sectors and national economies derive from forest ecosystems risk being wiped out (Nkem et al. 2007) and forest users will have to adjust accordingly as the forest ecosystems change (Spittlehouse and Stewart 2003). 
Some climate change impacts on forest are inevitable (Hamann and Wang 2006), but could be reduced to a certain extent in some places through planned adaptation of forest management (Spittlehouse and Stewart 2003). In the past, forest ecosystems have been adapting autonomously to disturbances including climate impacts (Smith et al. 2000). The increasing vulnerability of forest ecosystems as a result of several interrelated factors (climatic and non-climatic) indicates that autonomous adaptation of forests is insufficient to resist the current and projected future impacts of the changing climate. Adaptation in natural systems is a response to actual or expected climate stimuli or their effects, which moderates harm or exploits beneficial opportunities and it represents ways of reducing vulnerability (IPCC 2001b; Smith and Wandel 2006). Planned adaptation that puts in place and pursues the right policies and management interventions is crucial to facilitating adaptation (Niang-Diop and Bosch 2005) and increasing resistance and resilience of forest ecosystems to climate change. This raises certain pertinent questions that this paper aims to address, for example, the extent to which current forest management policies, regulations and practices in Burkina Faso and Ghana consider the need for climate change adaptation, and how well they can cope with future climate change impacts. The objectives of the paper are therefore (1) to highlight the suggested adaptation actions in forest management necessary under climate change, and (2) to identify potential elements of current forest policies and management practices in Burkina Faso and Ghana relevant to the suggested adaptation actions.

\section{Methods}

This study uses a comparative analysis approach in looking at some selected practices and current national policies on forest resources in Burkina Faso and Ghana in relation to a set of proposed adaptation measures for forest gathered from various studies (Table 1). How these vary between the two countries is also highlighted. The comparative analysis was carried out using document review and expert judgements and consultations. In the context of this study, policy statements are actual commitments translated into actual practices on the ground. This is made operational by identifying specific policy statements and the policy measures put in place that are relevant for the adaptation of forests to impacts of climate change. Laws, regulations, programmes and projects are considered in this study as policy measures put in place to implement and achieve specific policy statements. Some of the programmes and projects on the ground, however, may not necessarily have a connecting policy in place (Shankland 2000), which could be helpful in identifying gaps, bottlenecks and also strengths of existing forest policies and practices for climate change adaptation. But first, we highlight a set of recommended adaptation actions from various studies.

\section{Adaptation actions in forest management}

Many studies, as illustrated in Table 1, have recommended actions in forest management that could be relevant to adaptation to climate change (Spittlehouse and Stewart 2003). The basis of all these recommended actions consists of appropriate policies and management plans (Price and Neville 2003). According to Guariguata et al. (2007), current practices in sustainable forest management need to be reassessed in the light of observed and projected changes in climate and climate variability. Re-examining present forest policies and 
Table 1 A summary of adaptation actions in forest management under climate change

\begin{tabular}{|c|c|c|}
\hline Topic & Adaptation actions & Studies/references \\
\hline Gene management & $\begin{array}{l}\text { Reassessing conservation and seed banks } \\
\text { locations, breeding pest resistant genotypes, } \\
\text { determining adaptability and responses of } \\
\text { genotypes will be necessary for the genetic } \\
\text { diversity and resilience of tree species to } \\
\text { climate change }\end{array}$ & $\begin{array}{l}\text { Namkoog (1984), Peters (1990), } \\
\text { Rehfeldt et al. (1999), Parker et al. } \\
\text { (2000), Tyree (2003), FAO (2007), } \\
\text { Koskela et al. (2007) }\end{array}$ \\
\hline Forest protection & $\begin{array}{l}\text { Forest fire and pest management to reduce } \\
\text { disturbance, restore destroyed forest and } \\
\text { protect trees against diseases }\end{array}$ & $\begin{array}{l}\text { Stocks et al. (1998), Volney and } \\
\text { Fleming (2000), Dale et al. (2001), } \\
\text { Wheaton (2001), FAO (2005), } \\
\text { Guariguata et al. (2007) }\end{array}$ \\
\hline $\begin{array}{l}\text { Forest } \\
\text { regeneration }\end{array}$ & $\begin{array}{l}\text { Use drought tolerant genotypes, use artificial } \\
\text { regeneration and control invasive species }\end{array}$ & $\begin{array}{l}\text { Farnum (1992), Ledig and Kitzmiller } \\
\text { (1992), Dixon et al. (1996), Parker } \\
\text { et al. (2000), Noss (2001) }\end{array}$ \\
\hline $\begin{array}{l}\text { Silvicultural } \\
\text { management }\end{array}$ & $\begin{array}{l}\text { Selective removal of poor adapted trees, reduce } \\
\text { rotation period, manage forest density, species } \\
\text { composition, and forest structure to control the } \\
\text { declining and disturbed stands }\end{array}$ & $\begin{array}{l}\text { Farnum (1992), Dixon et al. (1996), } \\
\text { Lindner et al. (2000), Papadopol } \\
\text { (2000), Dale et al. (2001), } \\
\text { Guariguata et al. (2007) }\end{array}$ \\
\hline Forest operations & $\begin{array}{l}\text { Increased logging from disturbed stands, forest } \\
\text { carbon management, increase use of woodfuel } \\
\text { from forest, and put in place appropriate } \\
\text { policies to ease adaptation actions }\end{array}$ & $\begin{array}{l}\text { Burton et al. (2002), Perez-Garcia et } \\
\text { al. (2002), Spittlehouse and Stewart } \\
\text { (2003) }\end{array}$ \\
\hline $\begin{array}{c}\text { Non-timber } \\
\text { resources }\end{array}$ & $\begin{array}{l}\text { Minimize habitat fragmentation, conserve } \\
\text { wildlife, maintain primary forest, and } \\
\text { diversity of functional groups }\end{array}$ & $\begin{array}{l}\text { Peters (1990), Holling (2001), Noss } \\
\text { (2001), Stenseth et al. (2002), } \\
\text { UNCBD (2007) }\end{array}$ \\
\hline $\begin{array}{l}\text { Park and } \\
\text { wilderness area } \\
\text { management }\end{array}$ & $\begin{array}{l}\text { Plant adapted species, conserve biodiversity } \\
\text { and maintain connectivity and employ } \\
\text { adaptive management to influence change }\end{array}$ & $\begin{array}{l}\text { Cohen and Miller (2001), Suffling } \\
\text { and Scott (2002), Carey (2003) }\end{array}$ \\
\hline
\end{tabular}

Source: Adapted from Spittlehouse and Stewart (2003)

management practices in Burkina Faso and Ghana could provide the opportunity for realignment of existing policies and forest management practices to address climate change adaptation through the identification of gaps as well as intervention points to achieve sustainable forest management planning that incorporates adaptation strategies. By 'sustainable forest management' we mean enhancing the provision of forest goods and services to support present and future human well-being while ensuring lasting resistance, resilience and functional and biological diversity of forest ecosystems (Sayer et al. 1997) to cope with disruptive shocks and trends of climate change.

\section{Forest fires protection}

Climate change effects of drought, heat waves, strong winds and drier conditions (IPCC 2001a) increase the intensity, frequency and seasonality of forest fires disturbances (Biringer 2003), as observed in Burkina Faso and Ghana especially during the disastrous bushfires of 1982-1983 and 1983-1984 in Ghana (Ampadu-Agyei 1988). These disturbances can (a) pose major constraints to conservation and sustainable forest management (FAO 2000), (b) change the forest age class distribution and landscape 
pattern (Wheaton 2001) and change diversity and productivity in forest ecosystems (Savadogo 2007), and (c) in conjunction with shifting cultivation, can result in poor herbaceous vegetation dominated by fire tolerant species (Louppe et al. 1995). Forest fire management is seen as an adaptation measure important to forest protection (Reilly and Schimmelpfennig 1999; FAO 2005). Policies and management practices of forest fires in most West African countries are inadequate and hardly based on sound studies (Sawadogo 2006).

The 1998 'Politique Forestière Nationale' of Burkina Faso acknowledged the destruction caused by wildfires to the country's forests. There are clearly defined policy statements and laws in Burkina Faso (Articles 52, 53, 88, 258, 259, and Law No 006/97/ADP of 31 January 1997 of the Forestry Code) on the prohibition of setting bushfires in the forest and the ensuing fines, but without any elaborated strategies on the management of forest fires (MEE 1997, 1998). In 2006 'Stratégie National de Gestion des Feux en Milieu Rural' was formulated with the aim of minimising the damages caused by forest fires by rather using prescribed early fire and making maximum use of fires as a tool in sustainable forest and agricultural management (MECV 2006), in order to reduce the general poverty in rural areas and enhance the livelihoods of forest communities as outlined in Burkina Faso's national strategy for poverty reduction (MECV 2003; MEF 2004).

Article 5.3.11 of Ghana's Forest and Wildlife Policy (GFWP) stipulates that 'forest fires will be prevented and suppressed through integrated actions' (MLF 1994). The amended Forest Protection Act 624 of 2002 further stipulates that 'those who set fire in the forest will be punished'. Ill-equipped National Disaster Management Organisation, Ghana National Fires Service, Agricultural Extension Services, National Police Services, Department of Game and Wildlife and Community Fire Volunteer Squads have been put in place to monitor, mobilise, report and suppress bushfires (Ampadu-Agyei 1988). In practice, however, not much was done to protect the forest against forest fires (MLFM 2006). In the cases of both Burkina Faso and Ghana the policies were mostly prohibitive requiring enforcement and punishment to serve as deterrent especially to arson fires, which are not necessarily management strategies.

Recently in Ghana, a National Wildfire Management Policy with a more proactive, pragmatic and comprehensive framework was formed in 2006 to guide the government's actions towards wildfire management (MLFM 2006). The policy 'seeks to promote effective and efficient management of wildfire for sustainable management of natural resources and maintenance of environmental quality on the socio-economic well being of the citizens' (MLFM 2006, p. 8). Detailed policy strategies to be put in place have been outlined ranging from prevention and control to resource management options, stakeholders participation and more research on wildfire management. Projects on wildfire in Ghana include the 'Bushfire Control and Management in the Transitional Zone and the Reduction of Bushfires Impact on Forest Reserves 1999-2000' (JICA 1999). Even with these new policies, there is no evidence of considerations of climate change in the elaboration of policy now or in the future.

Forest fires in Burkina Faso are considered to have both positive and negative impacts on biotic and abiotic composition as well as human activities (MECV 2006). According to $\mathrm{MECV}$, negative impacts of forest fires on forest flora and fauna include reduced tree productivity, modification of flowering of certain tree species, poor fruiting of certain tree species, increased pest attacks on some tree species, game habitat destruction, game migration and reduced fodder for livestock. Positive impacts on flora and fauna include germination of certain tree species, growth of young and fresh fodder for livestock in the dry season, increased fruiting of certain tree species and reduced pathogenic attacks on 
certain tree species. Some measures have been put into place in some areas through project and bilateral agreements and actions. In Burkina Faso, reports from the four-year programme on forest fire control that started in 1998 have strengthened the institutional management capacity of organisations working against forest fires (UNCCD 2002). The reports revealed that forest fires are a considerable factor contributing to deforestation in Burkina Faso. The project developed forest fire management systems through research and development. It also improved the abilities of some forest fringe communities to manage forest fires through prescribed burning. As a result their living conditions have been enhanced and the vulnerability to fire of both the forest ecosystem and forest dependentcommunities reduced. This constitutes an important step toward adaptation with considerable potential for expansion into an adaptation strategy with the integration of other climate change dimensions and projections.

Forest fires remain the major single threat to Ghana's forest resources and account for an increasing annual loss of 3\% (US\$24 million) of the gross domestic product (FORIG 2003). The loss of forest resources to wildfires has greatly affected the local hydrology and numerous non-timber forest products that the local communities depend on (MLFM 2006). This has greatly exacerbated the already existent problems of poverty, poor health and diseases, further increasing the vulnerability of local communities. FORIG (2003) found that Milicia excelsa and Antiaris toxicaria are likely to be more fire tolerant than other species for enhancing forest recovery in Ghana. Despite all the incurred economic losses through fire, there are no climate considerations in the planning for responses to fires despite an IPCC projection of increased intensity and frequency of fire events.

An effective framework for cooperation in transboundary national parks and protected areas already exists on the prevention and control of wildfires between Ghana and Burkina Faso (FAO 2004). The two countries have agreed on a number of guiding principles on wildfire management that include compatibility of natural resource management objectives with the dynamics of the fire regime; holistic wildfire management, protection, planning, prevention, suppression and rehabilitation; safety wildfire management activities and costeffective resource management. Collective response is an important step towards adaptation especially for transboundary situations. However, the operational strategies require climate proofing that is supported by policies.

\section{Management of forest genetic diversity}

The genetic diversity of forest plays a vital role in maintaining the resilience of tree species against the impacts of climate change (Biringer 2003; Koskela et al. 2007). Policies and management strategies for forest genetic diversity may influence future forest ecosystem resistance and resilience as well as the flow of forest ecosystem goods and services (Thorsen and Kyær 2007). The term 'forest genetic diversity' here refers to genetic variation within tree species, provenances or individuals trees or clones of forest ecosystems (Thorsen and Kyær 2007). The management of forest genetic resources in Burkina Faso and Ghana has long been in existence. Forest policies in these countries, however, lack both articulated policy statements concerning forest genetic diversity and well established strategies and activities on forest genetic resource management.

The 1995 'Politique Forestière Nationale' of Burkina Faso (Section 2.1.2) and Burkina Faso 1997 Forestry Code (Articles 7, 35, 45, 48, 85 and 88) have open statements without specific action plans on the conservation of biological diversity. In Ghana, section 3.2.2 of GFWP superficially mentioned conservation of genetic resources as being important to life- 
sustaining processes. However, the two countries are involved in the management of their forest genetic resources at national, community and household levels. Forest tree species of local, national and global socio-economic value, which merited priority attention in the various operational fields ranging from exploration and conservation to breeding and local and large-scale uses, have been listed (Table 2). Most of these species are rare, endangered and vulnerable to both climatic and non-climatic conditions (Maiga 2002).

Limitations to the management of forest genetic diversity in Burkina Faso and Ghana include lack of facilities (infrastructure, transportation), insufficient and inefficient personnel, lack of new technology and insufficient financial resources for operations that require substantial development (Nikiema et al. 2001; Siaw 2001). In-situ conservation activities are carried out in forest reserves in the two countries where most of the useful tree species are found. Ghana has arboreta at Subri Forest Reserve, Pra-Anum Forest Reserve and Bobiri Forest Reserve (Peprah 1999). Sacred forests are scattered all over Ghana while traditional agroforestry parklands and community forests are common in both countries. Ex-situ conservation activities are: (a) non-lasting seed banks such as in deep freezers in Ghana and insufficient, small-scale seed banks of the Forest Research Institute of Ghana and National Forest Seed Centre in Burkina Faso (Peprah 1999; Nikiema et al. 2001) and (b) enrichment planting in Ghana, as a means to increase the stock of valuable tree species (Siaw 2001).

Selection and generic improvement activities exist in Burkina Faso and Ghana, but they have been far less successful due to insufficient financial resources to manage and monitor the field sites for a longer period of time. These activities are carried out through provenance trials to conserve gene pools and to learn the extent of genetic variation within

Table 2 Priority tree species for forest genetic resources conservation in Burkina Faso and the savannah region of Ghana

\begin{tabular}{|c|c|}
\hline Savanna region of Ghana & Burkina Faso \\
\hline $\begin{array}{l}\text { Acacia nilotica (L.) Wild. ex Delile } \\
\text { Acacia polyacantha Wild. } \\
\text { Acacia seyal Del. } \\
\text { Acacia sieberiana DC. } \\
\text { Afzelia Africana Smith ex Pers. } \\
\text { Adansonia digitata L. } \\
\text { Albizzia lebbeck (L.) Benth. } \\
\text { Azadirachta indica A. Juss. } \\
\text { Anogeissus leiocarpus (DC.) Guill. et Perrott } \\
\text { Ceiba pentandra (L.) Gaertn. } \\
\text { Combretum molle R. Br. ex G. Don } \\
\text { Detarium senegalense Gmel. } \\
\text { Diospyros mespiliformis Hochst. ex. A. Rich. } \\
\text { Faidherbia albida Del. Chev. } \\
\text { Khaya senegalensis (Desr.) A. Juss. } \\
\text { Lannea acida A. Rich. } \\
\text { Mitragyna inermis (Wild.) Kuntze } \\
\text { Parkia biglobosa (Jacq.) R. Br. Ex G. Don } \\
\text { Senna siamea (Lam.) Irwin et Barneby } \\
\text { Tamarindus indica } \text { L. } \\
\text { Terminalia glaucescens Planch. } \\
\text { Vitellaria paradoxa Gaertn. F. }\end{array}$ & $\begin{array}{l}\text { Acacia albida Del. } \\
\text { Acacia senegal (L.) Wild. } \\
\text { Adansonia digitata L. } \\
\text { Anogeissus leiocarpus (DC.) Guill. et Perr. } \\
\text { Azadirachta indica A. Juss. } \\
\text { Balanites aegyptiaca (L.) Del. } \\
\text { Borassus aethiopum Mart. } \\
\text { Khaya senegalensis (Desr.) A. Juss. } \\
\text { Maerua crassifolia Forssk. } \\
\text { Parkia biglobosa (Jacq.) R. Br. Ex G. Don } \\
\text { Prosopis africana (Guill. et Perr.) Taub. } \\
\text { Sclerocarya birrea (A. Rich.) Hochst. } \\
\text { Tamarindus indica L. } \\
\text { Vitellaria paradoxa Gaertn. F. } \\
\text { Ziziphus mauritiana Lam. }\end{array}$ \\
\hline
\end{tabular}

Source: Adapted from Siaw (2001) and Nikiema et al. (2001) 
and between provenances throughout the species' native ranges (Tyree 2003) and providing a basis for selection of species for afforestation at different sites. Furthermore there are also clonal trials with seeds from clonal orchards to identify the extent of genotypic variation, which information could be utilised to maximise genetic gains in yield and other parameters (Leakey 1991).

\section{Forest regeneration and silvicultural management}

Sustainable forest management in Burkina Faso and Ghana under climate change will highly depend on successful natural regeneration (Kessler 1992; Gonzalez 2001) and silvicultural measures such as artificial regeneration through reforestation and afforestation activities. Climate change may not easily affect the existing mature forests (Noss 2001) because they are more resilient, but rather it is the regeneration phase that will be most vulnerable to the changing climate (Spittlehouse and Stewart 2003). Many policies and practices from national, community and household levels that promote reforestation, afforestation, restoration and rehabilitation of degraded lands exist in both Burkina Faso and Ghana. With the additional stress of increasing climate change and variability, these policies and practices, however, have their limitations.

Burkina Faso's 1995 Forest Policy and 1997 Forestry Code (Articles 8, 13, 14, 45, and 258) have described degraded areas to be reforested, afforested and regenerated to protect and preserve its forest resources, while in Ghana the GFWP emphasised the necessity of state, private and community levels reforestation initiatives towards restoring a significant proportion of the country's original forest cover (Sections 5.2, 5.3.8, 5.3.9, 5.5.6 of GFWP and the Timber Resource Management Amendment Act 617 of 2002).

Reforestation and afforestation programmes have existed for decades in Burkina Faso and Ghana, especially since the Sahelian droughts of the 1970s, but were not effectively implemented. These programmes sequester carbon and also increase the forest-based assets of multiple forest users, which cannot be overemphasised. Most of these programmes, however, focus on large-scale projects, mostly monoculture industrial plantations in the case of Ghana with less attention paid to small-scale natural and artificial regeneration at household farm and community levels. The government of Ghana has embarked on promotion of reforestation activities through large-scale plantation development and smallscale on-farm regeneration activities. Private companies such as Bonsu Vonberg Farms Ltd and government-managed forest reserves such as in the Volta and Ashanti Regions all plant Tectona grandis (teak) because of its high market value. Other species used for reforestation activities include Cedrela species, Cieba species, Khaya senegalensis (mahogany), and Triplochiton sclerokylon (wawa). Constraints to reforestation activities include problems of land and tree ownership, lack of legally binding contracts between communities and the government on the management and benefit sharing of planted trees, erratic and late rainfall causing drought and subsequent death of newly planted tree seedlings, destruction of trees and forest by rampant bushfires and inadequate logistical and human resources to manage and protect the tree resources (Kotey et al. 1998)

The government of Burkina Faso, under a special presidential initiative, launched an annual nation-wide reforestation campaign in 2003 (MECV 2006). Tree species commonly planted include Acacia nilotica, Acacia senegal, Ziziphus mauritiana, Eucalyptus camaldulensis, Azadirachta indica, Prosopis juliflora, Cassia siamea, Pakia biglobosa, Mangifera indica, Khaya senegalensis and Anacardium occidentale. During the 2005 campaign, about $93 \%$ of the seedlings planted were from private nurseries, while only $7 \%$ 
came from the government-owned National Centre for Tree Seedlings (MECV 2006). Major constraints to seedling development include the frequent occurrence of drought and damages caused by livestock encroachment. Other constraints to this reforestation programme include lack of prior consideration of suitability of tree species required during seedling cultivation in nurseries, lack of technical support by the forestry services, insufficient financial, material and logistic support, limited afforestation under unsecured land tenure and poor seedling quality (MECV 2006).

Most farmers in Burkina Faso lack the financial resources to buy seedlings to carry out artificial regeneration during the annual reforestation campaign and have therefore developed their own reforestation activities. They often rely on assisted natural regeneration by protecting young trees on their farmlands against bush fires and livestock destructions but cannot do much to mitigate the impacts of drought on young trees. They use silvicultural and coppicing techniques to re-grow pre-existing tree and shrub stumps through the selection and pruning of stems that sprout from tree stumps (Reij et al. 2005). Farmers in Burkina Faso cut trees at a height of 0.1 to $0.4 \mathrm{~m}$ above the ground in a sloping or inclined shape, and the trees regenerate either on the trunk (stem coppice) or from the base (basal coppice). Some farmers have used vegetative propagation to grow Acacia albida by cutting the plant roots so that they will grow to become adult trees (Kessler 1992).

The Ghana Timber Resource Management Amendment Act 617 of 2002 does not allow farmers to harvest timber even from their farmlands. When this timber is harvested by timber companies who have timber exploitation permits, farmers are not adequately compensated for the damages caused to their crops (Nketiah et al. 2005). This has demotivated farmers in Ghana to the extent of destroying young naturally regenerated trees on their farmlands and staying away from planting trees. Some farmers in the charcoal producing area of Kintampo North and South District of Ghana, however, practice assisted natural regeneration by cutting tree stumps above the ground in a V-shape to facilitate basal, stem and root coppices (DEAR 2005). These tree cutting techniques minimise damages to the stem and the bud, prevent bruising, bark tearing and bud damage. Most of the natural regeneration efforts by the government failed due to ill planning, uncoordinated efforts, lack of resources and lack of incentives for farmers similar to the case in Burkina Faso. This failure in intervention policy has led to deforestation and degradation.

\section{Non-timber forest products}

Non-timber forest products (NTFP) such as fuelwood, fodder, bushmeat, wild fruits and vegetables represent the subsistence and economic base of many forest-dependent poor in Burkina Faso and Ghana, often serving as buffer and safety net (Wunder 2001). These roles of buffer and safety net are likely to become more important because of climate-induced crop failure and famine in climatically marginal agricultural areas (Dudley and Stolton 2003). Climate change and variability manifested through inadequate rainfall is amongst the major drivers of forest resource degradation in Burkina Faso leading to low NTFP production (Eyog Matig et al. 2002). Despite the importance and contribution of NTFP to poor livelihoods, forest policies in Burkina Faso and Ghana regarding NTFPs focus primarily on forest game (this paper considers game as NTFP). In both Ghana's Forest and Wildlife Policy and the Forestry Code of Burkina Faso wildlife (game) is, however, considered a major section with clear and detailed policy objectives and strategies. In some cases, wildlife management overlaps with the tourism sector. 
The financial benefit of timber production by the Ghana government through tax collection and concession fees dominates the 1994 Forest and Wildlife Policy. The lack of clear accrued financial benefits from NTFPs with the exception of game (Section 2.3, 2.4, 4, 5.2, and 5.4 of GFWP) has led to the lack of acknowledgement of the role of NTFPs in the livelihood strategies of poor people in the GFWP. Pressure exerted by rising woodfuel demand from the forest for household use was, however, raised as an issue to be addressed, but no concrete strategies and activities were put in place. Over the years, the everincreasing demand and consumption of woodfuel by poor households has resulted in the formation of a draft 'National Woodfuel Policy' by the Ministry of Energy.

Increased demand for bushmeat has led to the overexploitation of wildlife and extensive modification of wildlife habitats in Ghana. About $70 \%$ of the country's original 8.22 million ha of closed forest has been destroyed, and the deforestation rate is put at $220 \mathrm{~km}^{2}$ per annum (Bojo 1996). Most wild animal species are believed to be seriously depleted and at least 18 of the 222 mammalian species recorded in Ghana are under threat (Desanker 2002). Climate change will add an additional stressor and may lead to changes in habitats, causing species migration or extinction for both plants and animals (Elasha et al. 2007). This may further hamper the activities of the tourism sector.

Similarly, the 1997 Forestry Code under Section 2 and the 1995 'Politique Forestière Nationale' of Burkina Faso under Article 56 and 260 have mentioned forest fauna and woodfuel. With the exception of game and woodfuel, no policies and management plans exist for NTFPs, especially for high-value tree species such as Vitellaria paradoxa (shea butter) and Parkia biglobosa, including the forest-fodder-dependent livestock sector that has been substantially contributing to the gross domestic product of Burkina Faso. Income from the exportation of shea butter products is the third highest contributor to the gross domestic products of Burkina Faso after gold and cotton (Eyog Matig et al. 2002). Communities are authorised without permission to collect deadwood from the reserved forest for subsistence use, but they are not allowed to cut down living trees without permits. Many forest communities in Burkina Faso today carry out forest management for rural fuelwood market supply, where communities are licensed with management powers by the state or its agents. Each community, in collaboration with state agents, develops a management plant for its forest, stating the quota of wood to be extracted each year for sale (Kaboré 2005). Revenues from fuelwood sale are then partitioned based on agreed percentages by the parties involved (Kerkhof and Konate 2001).

\section{Discussion}

Due to lack of means (financial, material and human capacity) to effectively implement existing policies (Wiggins et al. 2004; Warren 2005), current practices have fallen short of effectively increasing the adaptive capacity of forest ecosystems to growing disturbances (both climatic and non-climatic) especially since the great droughts of the 1970s in Burkina Faso and the 1982-1983 and 1983-1984 fire outbreaks in Ghana. Different mixes of policies and actions are therefore necessary to enforce and climate-proof current practices to help the forest adapt to present and future climate disturbances in Burkina Faso and Ghana.

\subsection{Mainstreaming adaptation}

It is necessary to mainstream adaptation into national forest policies (Guariguata et al. 2007), especially in risk management planning. Forests, however, are still widely seen in 
Burkina Faso and Ghana as carbon sinks especially through Clean Development Mechanism projects, which, according to most forest planners and managers, simply entail payments for the planting of trees for carbon sequestration without any further technical and management aspects relevant for adaptation of forest practices to ensure the sequestration of carbon. Burkina Faso and Ghana are still at an early stage of mainstreaming climate change. Most climate mainstreaming initiatives range from broader environmental objectives to climate change initiatives comprising both mitigation and adaptation issues to agreements specifically aiming at integrating climate change adaptation (Gigli and Agrawala 2007). Ghana is using Strategic Environmental Assessment as an analytical and participatory approach to strategic decision making for mainstreaming climate change into sectoral policies, plans and programmes. (For more on Strategic Environmental Assessment, check UNEP et al. 2007) Burkina Faso on the other hand does not yet have any well-defined strategy for mainstreaming adaptation into forest and other development policies (Raben 2008). Mainstreaming adaptation into forest policies is a right step towards reducing vulnerability, but there is no guarantee that adaptation actions will be implemented because of insufficient human, material and financial resources, coupled with socio-cultural and political constraints. Although current forest policies in these countries already have many objectives and strategies that sound great, in effect only few of them are actually implemented.

\subsection{Capacity building and raising awareness}

Capacity building and raising awareness are vital for forest managers and decision makers. Most forest managers and decision makers in Burkina Faso, Ghana and West Africa at large do not yet fully understand the science and concept of climate change and its present and future impacts on forest ecosystems, let alone putting in place policies and management intervention strategies to increase the adaptive capacity of forest ecosystems to climateinduced disturbances. These forest managers and decision makers (a) require special training on the role of forest in climate change mitigation and adaptation, (b) need to know how and when their current management practices can help or act as a constraint to both the forest and forest-dependent livelihoods to adapt to impacts of climate change and variability, (c) need to know how forest management practices can enhance forest ecosystems' roles in mitigation and adaptation and (d) need a high level of appreciation (political and management will) of the necessity to integrate and carry out climate risk management activities in the forest management plans.

\subsection{Financial resources}

Financial resources are needed for both the mainstreaming process and the implementation of adaptation actions including the funding and strengthening of existing practices relevant for adaptation. Different funding sources for management practices for adaptation activities have been categorised, ranging from national governments, bilateral and multilateral agencies, private sector entities, private foundations and Global Environmental Facility to micro-financing of innovative approaches such as a levy on carbon markets (Levina 2007). Private investors can invest in adaptation measures by providing income (Guariguata et al. 2007). This will be useful to adaptation actions such as the modified taungya system in the degraded transitional zone of Ghana where the government in partnership with community members is facing financial stress to properly manage these plantations. Most of the management practices, often implemented through project activities, are donor funded and 
these funds are not constant, which explains why most of the policies cannot be fully implemented with the limited government financial resources in both countries. The adaptation funds of the United Nations Framework Convention on Climate Change (Decision s 3/CMP.1, 28/CMP. 1, and 5/CMP. 2) could potentially provide financial support to adaptation projects and programmes of eligible countries (UNFCCC 2007), which Burkina Faso and Ghana are. How accessible these funding sources for adaptation activities are remains to be seen.

\subsection{Socio-cultural and political dynamics}

Socio-cultural and political dynamics on the management of forest and trees must not be neglected. Forest outside reserves and trees on farmlands (woodlots, agroforestry and farm forestry) in Burkina Faso and Ghana are being managed by communities and individuals especially smallholder farmers who have developed these practices into a culture and technology. Forest and tree managers should therefore be looked at in a broader sense that includes private tree plantation owners and smallholder farmers. A successful adaptation of forest management to the impacts of climate change and variability in this situation will be partly influenced by the landscape dynamics and socio-cultural variables (Dixon et al. 1996; SP/CONAGESE 2001). For example, bush burning and slash and burn are cultural practices for land preparation, entrenched into the life style of farmers in Burkina Faso and Ghana (Ampadu-Agyei 1988; SP/CONAGESE 2001; Apusigah 2006). Unfortunately, the laws used by traditional and government institutions to control bushfires are not respected as sanctions are not implemented and re-enforced, which has helped bushfires to become endemic, occurring every year and destroying huge areas of forests and farmlands. Another example are the conflicting policy agendas of forest and agriculture ministries which aim at, respectively, growing or preserving more trees and growing more cotton. Forest agents in the south-western part of Burkina Faso encourage farmers to plant and maintain trees on their farmlands, while agriculture agents encourage farmers to cut down trees on their farmlands to give way for the cultivation of cotton. Because of the income generated from the sales of cultivation of cotton, most farmers prefer to grow cotton at the expense of forested lands being chopped down, reducing the assets of forests for adaptation and mitigation. Such a situation is rarely found in Ghana because land and forest are all under the same ministry.

\section{Recommendations}

A number of recommendations are suggested here following the analysis of existing policies and management practices. These include:

- There is need for motivation of forest fringe communities in Burkina Faso and Ghana through innovative incentives such as the facilitation of access to goods and services, provision of working materials and the provision of cash or material incentives, as they are best placed to prevent, suppress and control wildfires. This is important not only in the high economic forest areas of southern Ghana but also around the transitional zones of Ghana, where strong winds, droughts, and bushfires are depleting forest resources and making way for savannas and wooded land vegetation.

- It is appropriate to put in place policy and management mechanisms that ensure the harmonisation of conservation and the continued existence, evolution and accessibility 
of forest genetic resources especially to forest communities and farmers. Sharing of experiences especially in transboundary situations is crucial for adaptation; so is learning from and encouraging the use of innovative local methods used by farmers in Burkina Faso for crop seed storage, such as the use of granaries and lofts, ash and potash and use of insect repulsive plants (Ouedraogo et al. 2003), to store tree seeds in rural areas as they are cheap and simple to use.

- There is a need, based on sound research, for policy and management interventions that facilitate the spread and planting of genotypes more suitable to climate variability and changes as most of the tree seedlings under regeneration in Burkina Faso and Ghana do not undergo any kind of silvicultural screening for resistant provenances, especially to the harsh prevailing climate conditions.

- Policy incentives and management strategies need to be implemented that concentrate on improving the regeneration and growth of timber and non-timber forest products (Thomas and Samassekou 2003) on farmlands and outside forest reserves in order to reduce the increasing pressure on the utilisation of forest resources.

- To formulate polices and management strategies on the numerous non-timber forest products and their valorisation is important for enhancing the adaptive capacity of communities and sectors that depend on them.

- Further research is needed on the impacts of climate change and variability on different species of forest flora and fauna in order to build a database that will facilitate better forest management planning and practices in these countries.

Implementation of the above recommendations will require experienced and qualified forestry personnel, financial resources, active involvement of communities at all levels of forest management planning and the political will by decision makers and forest managers to mainstream adaptation into forest policy and management planning.

\section{Conclusion}

Forest ecosystems in Burkina Faso and Ghana provide valuable goods and services to society but are highly vulnerable to both climatic and non-climatic forces. Institutions and management are challenged to improve the adaptive capacity of forest ecosystems to the negative impacts of climate change by taking appropriate adaptation measures. The present forest policies in Burkina Faso and Ghana, however, lack clear objectives on climate change adaptation (and mitigation) but contain elements of risk management practices relevant to climate change adaptation. These management practices do not differ much from what most studies shown in 1 have suggested. Thus, integrating adaptation of forests (and mitigation) into forest policy as an objective with a clear strategy for implementation should strengthen current management practices and help to implement fully the entire forest policy objectives strategies as well as the formulation and development of policies on nontimber products while using a climate lens throughout the entire mainstreaming process.

Acknowledgements This document was produced with research funding by the European Union for the Tropical Forests and Climate Change Adaptation (TroFCCA) project. The contents of this document are the sole responsibility of the authors and can under no circumstances be regarded as reflecting the position of the European Union. The authors would like to thank two anonymous reviewers for their useful comments on an earlier version of this article, and the regional stakeholders who provided valuable information and access to national policy documents. 
Open Access This article is distributed under the terms of the Creative Commons Attribution Noncommercial License which permits any noncommercial use, distribution, and reproduction in any medium, provided the original author(s) and source are credited.

\section{References}

Ampadu-Agyei O (1988) Bushfires and management policies in Ghana. Environmentalist 8(3):221-228 doi:10.1007/BF02240254

Apusigah AA (2006) Promoting sustainable wildfire management in northern Ghana: learning from history. Eur J Soil Sci 2(2):109-123

Biringer J (2003) Forest ecosystems threatened by climate change: promoting long term forest resilience. In: Hansen LJ, Biringer JL, Hoffman JR (eds) Buying time: a user's manual for building resistance and resilience to climate change in natural systems. WWF, Berlin, Germany, pp 41-69

Blay D, Bonkoungou E, Chamshama SAO, Chikamai B (2004) Rehabilitation of degraded lands in subSaharan Africa: Lessons learned from selected case studies. Forestry Research Network for Sub-Saharan Africa and International Union of Forest Research Organizations Special Programme for Developing Countries

Bojo J (1996) The economics of wildlife: case studies from Ghana, Kenya, Namibia and Zimbabwe. AFTES Working Paper no. 19. Environmental policy and planning, Africa region. World Bank, Washington, DC

Burton I, Huq S, Lim B, Pilifosova O, Schipper EL (2002) From impacts assessment to adaptation priorities: the shaping of adaptation policy. Clim Policy 2:145-159 doi:10.1016/S1469-3062(02)00038-4

CARE International (2004) Study of Ghana's forest sector policies, laws, rules and regulations. CARE International

Carey AB (2003) Restoration of landscape function: reserves or active management? Forestry 76:221-230 doi:10.1093/forestry/76.2.221

Cohen S, Miller K (2001) North America, intergovernmental panel on climate change. Cambridge University Press, New York

Dale VH, Joyce LA, McNulty S, Neilson RP, Ayres MP, Flannigan MD et al (2001) Climate change and forest disturbances. Bioscience 51:723-734 doi:10.1641/0006-3568(2001)051[0723:CCAFD]2.0.CO;2

DEAR (2005) Charcoal burning in the Kintampo Districts: policies, environment and livelihood issues. Decentralised Environmental Action Research. The DEAR Project, Workshop held at Agricultural Department, Kintampo North District, 29 June 2005, Ghana

Desanker PV (2002) Impacts of climate change in Africa. WWF Climate Change Programme, Berlin, Germany

Dixon RK, Perry JA, Vanderklein EL, Hiol FH (1996) Vulnerability of forest resources to global climate change: case study of Cameroon and Ghana. Clim Res 6:127-133 doi:10.3354/cr006127

Dudley N, Stolton S (2003) Ecological and socio-economic benefits of protected areas in dealing with climate change. WWF Climate Change Programme, Berlin, Germany

Elasha OB, Medany M, Niang-Diop I, Nyong T, Tabo R, Vogel C (2007) Background paper on impacts, vulnerability and adaptation to climate change in Africa, for the workshop on adaptation implementation of decision 1/cp10 of the UNFCCC convention. Accra, Ghana, 21-23 September, 2006, UNFCCC

EPA (2000) 1st National Communication of Ghana to the United Nation Framework Convention on Climate Change. Environmental Protection Agency, UNFCCC

Eyog Matig O, Gaoué OG, Dossou B (2002) Réseau espèses ligneuses alimentaire. Compte rendu de la première réunion du réseau tenue 11-13 Décembre 2000 au CNSF Ouagadougou, Burkina Faso. Institut International des Ressources Phytogénétiques

FAO (2000) Actes de l'atelier sous-régional sur les statistiques forestières et perspectives pour le secteur forestier en Afrique/FOSA sous région ECOWAS Yamoussoukro, Côte d'Ivoire, 13-18 December 1999. FAO, Rome

FAO (2004) African Forestry and Wildlife Commission Fourteenth Session. Wildland Fire Agreements. Accra, Ghana, 18-21 February 2004, FAO

FAO (2005) Impact of climate change, pests and disease on food security and poverty reduction. Special event background document for the 31st session of the committee on world food security. Rome, 23-26 May 2005

FAO (2006) Global forest resources assessment 2005, progress towards sustainable forest management. FAO, Rome, Italy 
FAO (2007) Adaptation to climate change in agriculture, forestry and fishery: perspectives, framework and priorities. Interdepartmental working group on climate change. FAO, Rome, Italy

Farnum P (1992) Forest adaptation to global climate change through silvicultural treatments and genetic improvements. Department of Geography, University of Waterloo, Waterloo, Ont. Occasional Paper No. 15 , pp. $81-84$

Forest Research Institute of Ghana (FORIG) (2003) Final technical report: forest fire management in Ghana. Forest Research Institute of Ghana, Kumasi

Gigli S, Agrawala S (2007) Stocktaking of progress on integrating adaptation to climate change into development co-operation activities, COM/ENV/EPOC/DCD/DAC(2007)1/final, OECD, Paris

Gonzalez P (2001) Desertification and a shift of forest species in the West African Sahel. Clim Res 17:217228 doi:10.3354/cr017217

Gray LC, Kevane M (2001) Evolving tenure rights and agricultural intensification in south western Burkina Faso. World Dev 29(4):573-587 doi:10.1016/S0305-750X(00)00115-7

Guariguata MR, Cornelius JP, Locatelli B, Forner C, Sanchez-Azofeifa GA (2007) Mitigation needs adaptation: tropical forestry and climate change. Mitig Adapt Strategies Glob Chang. doi:10.1007/ s11027-007-9141-2

Hamann A, Wang T (2006) Potential effects of climate change on ecosystems and tree species distribution in British Columbia. Ecology 87(11):2773-2786 doi:10.1890/0012-9658(2006)87[2773:PEOCCO]2.0.CO;2

Holling CS (2001) Understanding the complexity of economic, ecological, and social systems. Ecosystems (N Y, Print) 4:390-405 doi:10.1007/s10021-001-0101-5

IPCC (2001a). Climate change 2001. Impacts, adaptation and vulnerability. Third Assessment Report.

IPCC (2001b) Climate change 2001. Impacts, adaptation and vulnerability. In: McCarthy JJ, Canziani OF, Leary AA, Dokken DJ, White KS (eds) A contribution of the working group 2 to the third assessment report to the International Panel on Climate Change. Cambridge University Press, Cambridge

IPCC (2007) Fourth Assessment Report. Working group two, impacts, adaptation and vulnerability. Summary for policy makers

JICA (1999) Country profile on environment, Ghana. Japan International Cooperation Agency

Kaboré C (2005) Amenagement des forest au Sahel. Point sur vingt annees de pratique au Burkina Faso

Kalame FB, Idinoba M, Brockhaus M, Nkem N (2008) Forest policies and forest resource flow in Burkina Faso, Ghana and Mali: Conflicting or consistent for adaptation to climate change? TroFCCA Brief No 1. CIFOR, Bogor, Indonesia.

Kerkhof P, Konate AB (2001) The role of forestry in poverty alleviation: country profile prepared for the forum on the role of forestry in poverty alleviation. FAO, Rome

Kessler JJ (1992) The influence of karité (Vitellaria paradoxa) and néré (Parkia biglobosa) trees on sorghum production in Burkina Faso. Agrofor Syst 17:97-118 doi:10.1007/BF00053116

Koskela J, Buck A, Teissier du Cros E (eds) (2007) Climate change and forest genetic diversity. Implications for sustainable forest management in Europe. European Forest Genetic Resources Programme

Kotey ENA, Francois J, Owusu JGK, Yeboah R, Amanor KS, Antwi L (1998) Falling into place. Ghana policy that works for forests and people series no 4, IIED, London, UK

Leakey RRB (1991) Towards a strategy for clonal forestry: some guidelines based on experience with tropical trees. Royal Forestry Society of England, Wales and Northern Ireland, Tring, England

Ledig FT, Kitzmiller JH (1992) Genetic strategies for reforestation in the face of global climate change. For Ecol Manage 50:153-169 doi:10.1016/0378-1127(92)90321-Y

Levina E (2007) Adaptation to climate change: International agreements for local needs. Organisation for Economic Co-operation and Development and International Energy Agency

Lindner M, Lasch P, Erhard M (2000) Alternative forest management strategies under climate change: prospects for gap model applications in risk analyses. Silva Fenn 34:101-111

Louppe D, Ouattara NO, Coulibaly A (1995) The effects of bush fires on vegetation: the aubréville fire plots after 60 years. Commonw For Rev 74(4):288-292

Maiga AS (2002) Forest Genetic Resources Working Paper 12. Forest Resources Division, FAO, Rome, Italy

Ministère de l'Environnement et du Cadre de Vie (MECV) (2003) Décret portant utilisation des feux en milieu rural. Project gestion des feux en milieu rural, Burkina Faso

Ministère de l'Environnement et du Cadre de Vie (MECV) (2004) Contribution du secteur forestier a l'économie national et à la lutte contre la pauvreté, Burkina Faso

Ministère de l'Environnement et du Cadre de Vie (MECV) (2006) Stratégie national de gestion des feux en milieu rural, Burkina Faso

Ministère de l'Environnement et de l'Eau (MEE) (1997) Loi no 006/97/adp portant Code Forestier au Burkina Faso

Ministère de l'Environnement et de l'Eau (MEE) (1998) Politique Forestière National (annexes). Burkina Faso 
Ministère de l'Economie et des Finances (MEF) (2004) Cadre stratégique de lutte contre la pauvreté, Burkina Faso

Ministry of Lands and Forestry (MLF) (1994) Ghana Forest and Wildlife Policy. Ghana

Ministry of Lands Forestry and Mines (MLFM) (2006) Ghana National Wildfire Policy, Ghana

Namkoog G (1984) Strategies for gene conservation. In: Plant gene resources: a conservation imperative, 79-89. CW Yeatman, D Kafton, Wilkes (eds), American Association for the Advancement of Science, Selected Symposium 87, Boulder, CO

Niang-Diop I, Bosch H (2005) Formulating an adaptation strategy. In: Lim B, Spanger-Siegfried E (eds) Adaptation policy framework. Developing strategies, policies and measures. Cambridge University Press, Cambridge, pp 165-181

Nicholson S (2001) Climate and environmental change in Africa during the last two centuries. Clim Res 17:123-144 doi:10.3354/cr017123

Nikiema A, Ouedraogo SJ, Boussim J (2001) Situation des ressources génétiques forestières du Burkina Faso. Atelier sous-régional FAO/IPGRI/ICRAF sur la conservation, la gestion, l'utilisation durable et la mise en valeur des ressources génétiques forestières de la zone sahélienne (Ouagadougou, 22-24 Sept. 1998). Note thématique sur les ressources génétiques forestières. Document fgr/22f. Département des forêts, FAO, Rome

Nkem J, Santose H, Murdiyarso D, Brockhaus M, Kanninen M (2007) Using tropical forest ecosystem goods and services for planning climate change adaptation with implications for food security and poverty reduction. J Agric Res ICRISAT 4(1):1-23

Nketiah KS, Ameyaw JAS, Owusu B Jr (2005) Equity in forest benefit sharing: stakeholders' views. Tropenbos International, Ghana

Noss RF (2001) Beyond Kyoto: forest management in a time of rapid climate change. Conserv Biol 15:578590 doi:10.1046/j.1523-1739.2001.015003578.x

Ouedraogo LG, Sary H, Yameogo-Gamene CS, Neya O (2003) A participatory approach for conservation of forest genetic resources. In: Lemons L, Victor R, Schaffer D (eds) Conserving biodiversity in arid regions: best practices in developing countries. Kluwer Academic, Boston, pp 63-73

Papadopol CS (2000) Impacts of climate warming on forests in Ontario: options for adaptation and mitigation. For Chron 74:139-149

Parker WC, Colombo ML, Cherry ML, Flannigan MD, Grifenhagen S, McAlpine RS et al (2000) Third millennium forestry: what climate change might mean to forest and forest management in Ontario. For Chron 76:445-463

Peprah T (1999) National report on forest genetic resources in Ghana. Training workshop on FGR. 6-11 December 1999, Nairobi, Kenya

Perez-Garcia J, Joyce LA, McGuire AD (2002) Temporal uncertainties of integrated ecological/economic assessments at the global and regional scales. For Ecol Manage 162:105-115 doi:10.1016/S0378-1127 (02)00053-1

Peters RL (1990) Effects of global warming on forests. For Ecol Manage 35:13-33 doi:10.1016/0378-1127 (90)90229-5

Price MF, Neville GR (2003) Designing strategies to increase the resilience of alpine/montane systems to climate change. In: Hansen LJ, Biringer JL, Hoffman JR (eds) Buying time: a user's manual for building resistance and resilience to climate change in natural systems. WWF, Berlin, Germany

Raben K (2008) A climate mapping study for Burkina Faso. Danish embassy, Ouagadougou, Burkina Faso

Rehfeldt GE, Ying CC, Spittlehouse DL, Hamilton DA (1999) Genetic responses to climate for Pinus contorta: niche breadth, climate change, and reforestation. Ecol Monogr 69:375-407

Reij C, Tappan G, Belemvire A (2005) Changing land management practices and vegetation on the central plateau of Burkina Faso. J Arid Environ 63:642-659 doi:10.1016/j.jaridenv.2005.03.010

Reilly JM, Schimmelpfennig D (1999) Agricultural impact assessment, vulnerability, and the scope for adaptation. Clim Change 43:745-788 doi:10.1023/A:1005553518621

Savadogo P (2007) Dynamics of Sudanian savanna-woodland ecosystem in response to disturbances. Doctoral thesis, no 2007:64. Faculty of Forest Sciences, Swedish University of Agricultural Science, Umeå, Sweden

Sawadogo L (2006) Adapter les approaches de l'aménagement durable des forêts sèches aux aptitude sociales, economique et technologiques en Afrique: Le cas du Burkina Faso. CIFOR, Indonesia

Sayer JA, Vanclay JK, Byron N (1997) Technologies for sustainable forest management: Challenges for the 21 st century. Commonwealth Forestry Congress. Victoria, Falls, Zimbabwe, May 1997, CIFOR Occasional Paper No 12

Shankland A (2000) Analysing policy for sustainable livelihoods. Research Report 49. IDS, Brighton

Siaw DEKA (2001) State of forest genetic resources in Ghana. Sub-regional workshop FAO/IPGRI/ICRAF on the conservation, management, sustainable utilization and enhancement of forest genetic resources in 
Sahelian and north-Sudanian Africa (Ouagadougou, 22-24 September 1998). FAO Forest Genetic Resources Working Papers, working paper fgr/17e. Forest resources division. FAO, Rome, Italy

Smith B, Wandel J (2006) Adaptation, adaptive capacity and vulnerability. Glob Environ Change 16:282292 doi:10.1016/j.gloenvcha.2006.03.008

Smith B, Burton I, Klein RJT, Wandel J (2000) An anatomy of adaptation to climate change and variability. Clim Change 45(1):223-251 doi:10.1023/A:1005661622966

SP/CONAGESE (2001) Communication national du Burkina Faso. Convention Cadre des Nations Unies sur les Changement Climatiques, Secrétariat Permanent du Conseil National pour la Gestion de l'Environnement au Burkina Faso. Ministère de l'Environnement et du Cadre de Vie, Burkina Faso

SP/CONEDD (2007) Programme d'action national d'adaptation à la variabilité et aux changements climatique (PANA du Burkina Faso), Secrétariat Permanent du Conseil Nationa pour l'Environnement et le Développement Durable, Ministère de l'Environnement et du Cadre de Vie, Burkina Faso

Spittlehouse DL, Stewart RB (2003) Adaptation to climate change in forest management. B C J Ecosyst Manage 4(1):1-11

Stenseth NC, Mysterud A, Ottersen G, Hurrell JW, Chan K, Lima M (2002) Ecological effects of climate change fluctuations. Science 297:1292-1296 doi:10.1126/science.1071281

Stocks BJ, Fosberg MA, Lynham TJ, Mearns L, Wotton BM, Yang Q et al (1998) Climate change and forest fire potential in Russia and Canada boreal forests. Clim Change 38:1-13 doi:10.1023/A:1005306001055

Suffling R, Scott D (2002) Assessment of climate change effects on Canada's national park system. Environ Monit Assess 74:117-139 doi:10.1023/A:1013810910748

Thomas I, Samassekou S (2003) Role of planted forests and trees outside forests in sustainable forest management in the Republic of Mali. Planted Forests and Trees Working Paper 28. Forest Resources Development Service, Forest Resources Division. FAO, Rome

Thorsen BJ, Kyær ED (2007) Forest genetic diversity and climate change: economic considerations. European Forest Genetic Resources Programme, pp 69-84

Tyree MT (2003) Hydraulic limits on tree performance: transpiration, carbon gain, and growth of trees. Trees (Berl) 17:95-100

UNCBD (2007) Biodiversity and climate change. International day for biological diversity. United Nations Convention on Biological Diversity

UNCCD (2002) Committee for the review of the implementation of the convention. Report by Finland. United Nations Convention to Combat Desertification

UNEP UNCCD, UNDP (2007) Generic guidelines for mainstreaming environment with particular focus on drylands issues into national development frameworks. Draft working paper, UNEP

UNFCCC (2007) Adaptation funding. Subsidiary body for implementation. Agenda item 10 adaptation funding. Twenty-seventh session, 3-11 December 2007, Bali

Volney WJA, Fleming RA (2000) Climate change and impacts of boreal forest insects. Agric Ecosyst Environ 82:283-294 doi:10.1016/S0167-8809(00)00232-2

Warren A (2005) The policy implications of Sahelian change. J Arid Environ 63:660-670 doi:10.1016/j. jaridenv.2005.03.006

Wheaton E (2001) Changing fire risk in a changing climate: a literature review and assessment, Publ. No. 11341-2E01. Saskatchewan Research Council, Saskatoon, Sask

Wiggins S, Marfo K, Anchirinah V (2004) Protecting the forest or the people? Environmental policies and livelihoods in the forest margins of southern Ghana. World Dev 32(11):1939-1955 doi:10.1016/j. worlddev.2004.05.008

Wunder S (2001) Poverty alleviation and tropical forests - what scope for synergies? World Dev 29 (11):1817-1833 doi:10.1016/S0305-750X(01)00070-5 